\title{
The weathering action of saxicolous lichens in maritime Antarctica
}

\author{
C. Ascaso ${ }^{1}$, L. G. Sancho ${ }^{2}$ and C. Rodriguez-Pascual ${ }^{1}$ \\ ${ }^{1}$ Instituto de Edafología y Biologia Vegetal, Serrano 115 bis, E-28006 Madrid, Spain \\ ${ }^{2}$ Departamento de Biología Vegetal II, Facultad de Farmacia, U.C.M., E-28040 Madrid, Spain
}

Received 29 March 1989; accepted 28 June 1990

Summary. Xanthoria elegans (Link) Th Fr. and Lecidea lapicida (Ach.) were studied on volcanic andesite, and Rhizocarpon geographicum (L.) DC. and Bacidia stipata Lamb on a volcanigenic sediment, using light microscopy, infrared spectroscopy, X-ray diffraction and transmission electron microscopy. Feldspars were present in the rocklichen interface to a lesser extent than in the underlying rock. $R$. geographicum was found to alter the minerals in the rock on which it grew without producing any new minerals in the rock/lichen interface, in contrast to the observations for this species on granite in temperate regions. Beneath of the thallus of $L$. lapicida there was calcium oxalate and some micas of the illite type, which may have been degradation products of various phyllosilicates in the rock. B. stipata, an endemic Antarctic lichen, had the greatest capacity to weather the rock and had weddellite (dihydrate calcium oxalate) and calcite in the contact area as well as many bacteria. The presence of crystalline oxalate, imogolite, allophane, carbonates (calcite) and amorphous material not found in the parent rock indicates biomineralization processes attributable to the lichens.

\section{Introduction}

Although the first studies of lichen which produced weathering of rocks led to the conclusion that this effect might almost be entirely ascribed to physical causes, it is known today that the lichen-rock interface is a place of considerable chemical activity, above all due to the fungal excretion of organic acids with chelating capacity (Jones and Wilson 1985). Within the fields of chemical weathering of the minerals forming the rock, two types were described by Duchafour (1979): (1) geochemical weathering, which takes place under the influence of water, and which is characterized by the crystallization of clay minerals and some oxides and hydroxides, and (2) biochemical weathering which is deeply influenced by the presence of organic matter and living organisms, producing non-crystallized and poorly organized matter. Within the types of bio- mineralization described, one of them is characterized by an extracellular and/or intracellular mineral formation without associated organic matrices; this is the type of biomineralization associated with the presence of rockencrusted lichen thalli (Jones and Wilson 1986). Using scanning electron microscope and energy dispersive X-ray analyses, a series of weathering processes caused by lichen crusts on rock minerals were described. The descriptions included etching, decomposition and secondary products (Jones et al. 1981). Such decomposition is carried out by lichen acids and oxalic acid. Jones et al. (1980) demonstrated the formation of calcium oxalate in the interface between basalt and Pertusaria corallina, and the formation of manganese oxalate by the same lichen growing on a mineral containing manganese (Wilson and Jones 1984). Glushinskite (magnesium oxalate) was also observed in the serpentinite interface colonized by Lecanora atra (Wilson et al. 1980, 1981). The action of oxalic acid had been described as of interest, particularly in the case of lichens living on limestone (Syers and Iskandar 1973). Ascaso et al. (1982) observed the effects of several encrusting lichens on crystalline limestone and crystalline dolomite as well as the formation of oxalate in the lichen-rock interface. But in addition to the crustose lichens, several saxicolous lichens showed the ability to weather the rock substrate (Ascaso et al. 1976; Galván et al. 1981).

While the importance of lichens as primary producers in the Antarctic terrestrial ecosystem has been described by Kappen and Friedmann (1983) and Kappen et al. (1986), few studies have concentrated on the possible role of lichens in the weathering of rocks in Antarctica. Lindsay (1978), who distinguished between the ecosystems of continental and maritime Antarctic, stated that the role of lichens in soil development was minimal, and in continental Antarctica even this activity is often totally subordinated to physical weathering processes. Walton (1985) found evidence of weathering under encrusted lichens from the South Orkney Islands.

The present study is concerned with rock weathering by some saxicolous lichens in the maritime Antarctic. Both cosmopolitan and endemic species were studied in order to compare the present results with those obtained by other 
aùthors in other areas. Both foliose and crustose lichen biotypes were represented.

\section{Material and methods}

The lichens used in this study were the foliose Xanthoria elegans (Link) Th. Fr. and the crustose Lecidea lapicida (Ach.) Ach., Rhizocarpon geographicum (L.) DC. and Bacidia stipata Lamb., collected from King George Island (South Shetland Islands) in January 1987. $X$. elegans and $L$. lapicida were collected from volcanic andesite, whilst $R$. geographicum and $B$. stipata were found on volcanigenic sediment classified as clastic.

The unweathered rock was studied by light microscopy, IR spectroscopy and X-ray diffraction (XRD).

To observe the zone of contact between lichen and rock, the specimens were embedded in the plastic Cronolita 1180, and polymerized at room temperature over a period of 15 days. Afterwards, the specimens were sectioned with a diamond saw at a thickness of $30 \mu$. The nature and composition of the mineral content of the interface substrate between the rock and lichen thallus was established by IR spectroscopy, energy dispersive X-ray analysis (XRD) and transmision electron microscopy (TEM) following the methods of Ascaso et al. (1976) and Ascaso et al. (1982). Samples for X-ray diffractometry were prepared by the powder method and also as air dried oriented aggregates, glycerol treated aggregates and aggregates calcinated at $500^{\circ} \mathrm{C}, 3 \mathrm{~h}$. However, the figures in the present study only show the results obtained with the powder method and air dried oriented aggregates.

\section{Results}

Light microscopy confirmed that the rocks beneath $X$. elegans and L. lapicida were volcanic andesite with phenocrysts of plagioclase, clino-pyroxene, orthopyroxene and opaque matter. The rocks on which $R$. geographicum and $B$. stipata were growing were a volcanigenic sediment, classified as clastite and consisting of plagioclase crystals, olivine, amphibole, pyroxene and fragments of plagioclaserich basalt.

Figure 1. shows a section through $X$. elegans and the underlying rock. The lobes of the thallus are clearly visible, and the zone of contact between lichen and rock appears as a well-defined line (Fig. 1, arrows). In some cases the upper edge of the thallus is clearly visible, while the lower part is not easily distinguished from the rock.

The L. lapicida - volcanic rock contact area is shown in Fig. 2a. Figure 2b shows the same area with crossed nicols (polarized light). In the case of $R$. geographicum, Fig. 3a shows the lichen-rock contact area with parallel nicols, and Fig. $3 b$ with crossed nicols. Figure $3 b$ shows with polarized light an important accumulation of minerals inside the lichen thallus (arrow), as opposed to Fig. $2 \mathrm{~b}$, where this phenomenon is not observed.

In the case of B. stipata, the rock always looks very weathered (Fig. 4a), where no well-defined contact area can be distinguished as in the previous figures. Crossed nicols make it also possible to see a large amount of loose minerals in the contact area (Fig. $4 b$ ).

Comparison of IR data from the lichen rock interfaces and the underlying rock are shown in Fig. 5. For the $X$. elegans interface the bands ascribed to the parent rock minerals, plagioclase and pyroxenes $(464,589,610$ and

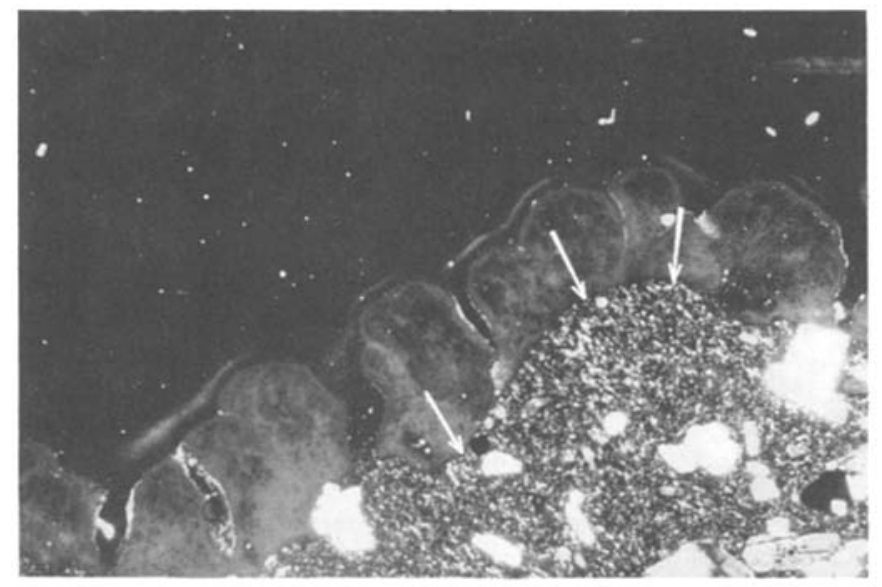

Fig. 1. Transverse section through Xanthoria elegans on volcanic rock. Crossed nicols (polarized light)

$724 \mathrm{~cm}^{-1}$ ) decrease greatly or even disappear. The band produced by the $\mathrm{SiO}_{2}$ group broadens and weakens with a maximum of $1050 \mathrm{~cm}^{-1}$, indicating possible phyllosilicate formation. There is a broad band with a maximum around $925 \mathrm{~cm}^{-1}$, where ions of the A1 $(\mathrm{OH})$ group participate. Another broad band of $\mathrm{Si}-\mathrm{O}-\mathrm{Al}$ with a maximum appears near $535 \mathrm{~cm}^{-1}$. Additionally, there is a large amount of amorphous material.

The IR study of L. lapicida shows that the rock spectrum has a very strong band due to $v \mathrm{Si}-\mathrm{O}$, with a maximum of $1085 \mathrm{~cm}^{-1}$, which together with the twin band $797-780 \mathrm{~cm}^{-1}$ is typical of a large part of the quartz minerals in this sample. The $v \mathrm{Si}-\mathrm{O}$ group has another band due to the remaining silicates which overlaps with that of quartz at a maximum of $1038 \mathrm{~cm}^{-1}$. The bands 464 , $589,610,649,724,744$ and 761 must be ascribed to feldspars. The IR study of the L. lapicida - rock interface gives little relevant information.

The IR study of the rock beneath $R$. geographicum, shows a well-defined maximum at $3540 \mathrm{~cm}^{-1}$ due to the $\mathrm{OH}$ groups of chlorite. The response of the $\mathrm{SiO}$ group reaches a maximum of $1010 \mathrm{~cm}^{-1}$ and peaks at 1150 and $1045 \mathrm{~cm}^{-1}$. In the spectrum of the lichen-rock interface a band forms at $945 \mathrm{~cm}^{-1}$ due to the $\mathrm{Al}(\mathrm{OH})$ groups, which may come from a laminar mineral. The band at $3540 \mathrm{~cm}^{-1}$ does not exist in the IR of the interface.

The IR of the rock beneath $B$. stipata has a spectrum typical for feldspars (bands at 589 and $610 \mathrm{~cm}^{-1}$ ). The lichen-rock interface has a band at $1400 \mathrm{~cm}^{-1}$, typical of carbonates (later confirmed by XDR). The interface appeared to contain much organic matter although the sample was heated with $\mathrm{H}_{2} \mathrm{O}_{2}$. Analysis by thermogravimetry (TG) showed a great inflection in the response curve between $220^{\circ}$ and $350^{\circ} \mathrm{C}$, a clear indication of organic matter. Visual observations (Fig. 4b) confirmed this and that the degree of rock destruction and the mixing of rock minerals with the thallus is greater in B. stipata than in the other thalli studied.

IR observations for all the lichen-rock interfaces show some of the weathering caused by the action of lichen thalli on the rocks. In the interface, bands present in the rock 

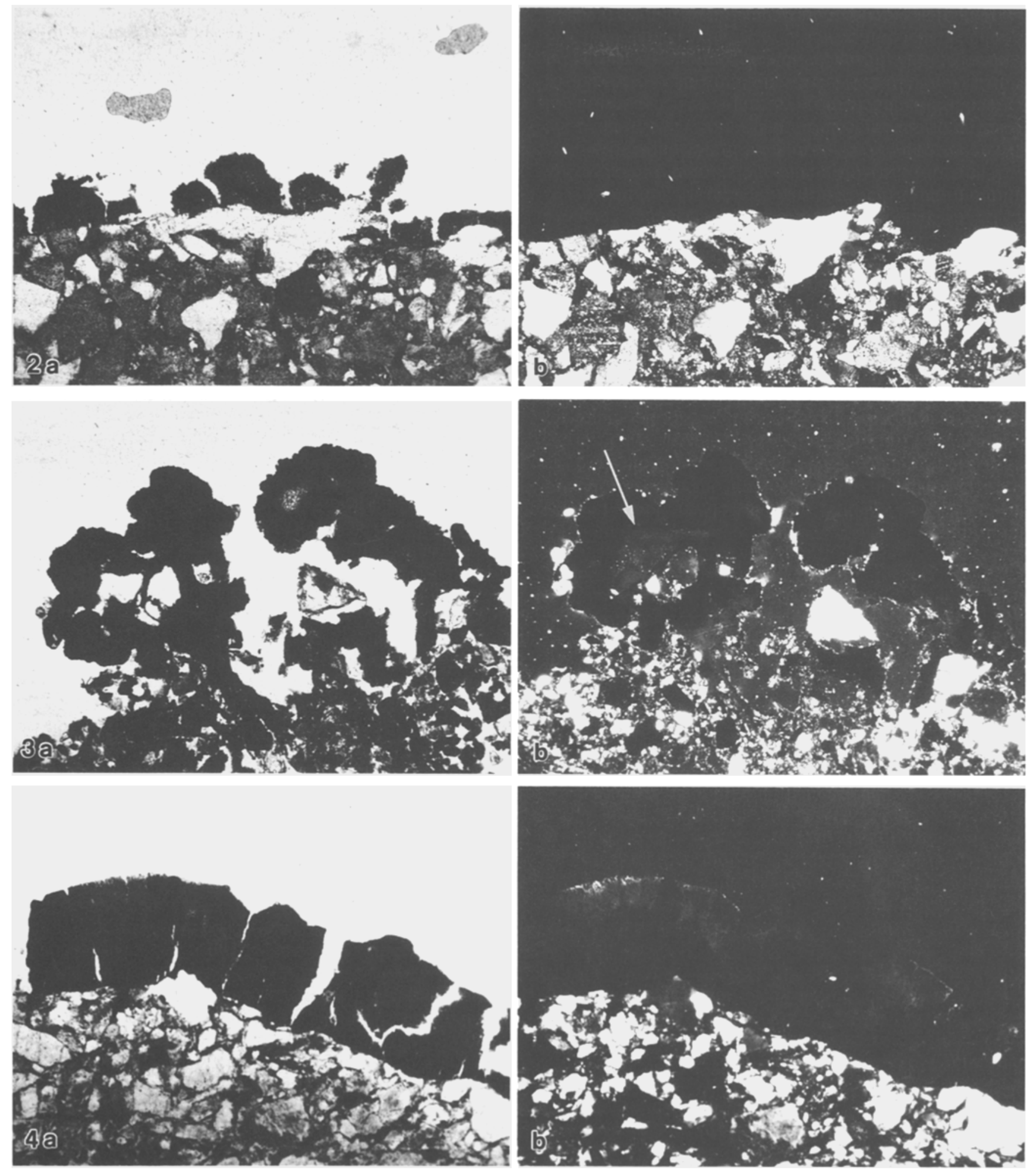

Fig. 2. a Transverse section through crustose lichen Lecidea lapicida on volcanic rock. Parallel nicols. b As in a but crossed nicols

Fig. 3. a Transverse section through crustose lichen Rhizocarpon geographicum on sedimentary rock. Parallel nicols. b. As in a but crossed nicols. The grey appearance inside the thallus is due to the mineral particle accumulated (arrow)

Fig. 4. a Transverse section through Bacida stipata on sedimentary rock. Parallel nicols. b As in a, but crossed nicols. Minerals adhering to the lower part of the thallus 


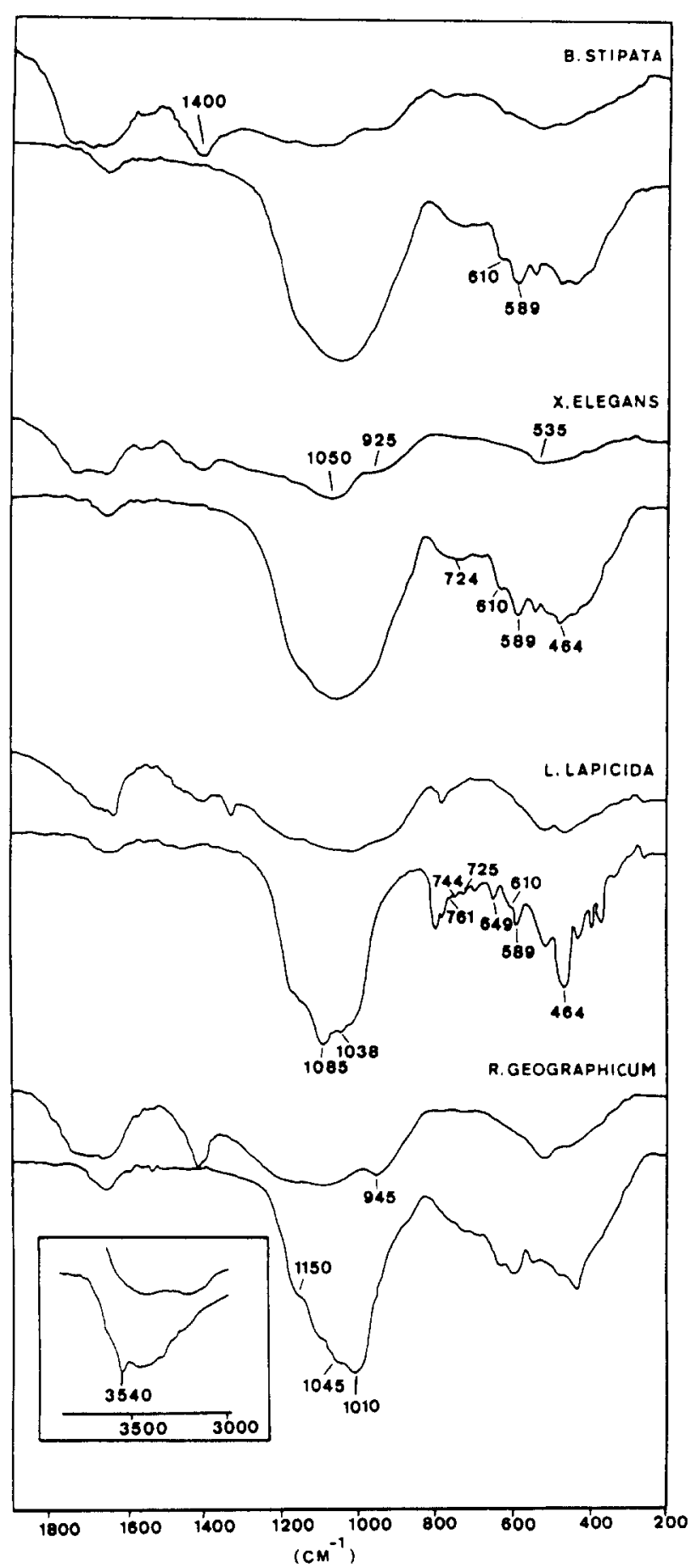

Fig. 5. IR spectra of rock (upper curve) and rock scraping between rock and lichen thalli (lower curve) of the four investigated species. The small diagram belong to $R$. geographicum

disappear, while other new bands appear. We believe that these new bands are attributable to phyllosilicate formation and are due to the $\mathrm{Al}(\mathrm{OH})$ group and $\mathrm{Si}-\mathrm{O}-\mathrm{Al}$ groups.

In each of the following figures $(6 a-d)$ the bottom diagram corresponds to the XRD of unweathered rock and the top one to the corresponding lichen-rock interface. In Fig. 6a the main components of the rock were feldsparsplagioclases with a little pyroxene. The typical spacings of these are $3.23,3.20$ and $4.05 \AA$. Comparison of the interface between $X$. elegans and the rock shows a decrease in the number of reflections due to feldspars indicating that the feldspars are in the process of transformation. In the interface, a band appears with not very well defined maxima between $2 \theta=16$ and 30 degrees which can be ascribed to amorphous material. Feldspar weathering identified by $\mathrm{X}$-ray diffraction was also found in the IR spectra.

In Fig. $6 \mathrm{~b}$ the main components of the rock are only feldspar-plagioclases and quartz (the most typical spacing of the latter being $3.34,4.26$ and $1.81 \AA$ ). Of all the rocks studied here, this is the one with the greatest number of phyllosilicates. Among the phyllosilicates found were mica $(9.9 \AA)$ and chlorite $(14.0,7.0$ and $4.70 \AA)$. Traces of pyroxene were also observed. Generally speaking, a decrease in the number of reflections was observed in the interface between $L$. lapicida and the rock. There are some peaks that can be ascribed to plagioclase and quartz, although the proportion between both is lower than in the rock. The amount of chlorite beneath the lichen is also lower than in the rock. Calcium oxalate $(6.02 \AA)$ and decayed micas or illite (at $10.15 \AA$ ) are also found. Amorphous material is present in this sample, but to a lesser extent than in the previous one.

Figure $6 \mathrm{c}$ shows diagrams for R. geographicum. For the rock, there are peaks typical of feldspar-plagioclases with a great amount of hydromagnesite and pyroxene, little chlorite and phyllosilicates. The hydromagnesite, $\mathrm{Mg}_{5}$ $\left[\mathrm{OH} \mid\left(\mathrm{CO}_{3}\right]_{2}\right)_{2} 4 \mathrm{H}_{2} \mathrm{O}$, has peaks at $6.55,5.88$ and $2.86 \AA$. Plagioclases are less numerous than in the previous rock specimen. In the oriented aggregate of the interface the peak at $14 \AA$ is very typical for chlorite, confirming the identification by means of IR. Further confirmation was obtained by swelling the mineral with ethylene glycol, which formed the pattern of chlorite-smectite. The chlorite-like mineral observed in the interface is the same mineral as that in the rock. The laminar minerals, phyllosilicates found in the rock and shown by the peaks 4.59 and $2.56 \AA$ are not visible at the same spacing in the interface spectrum. The intensity of the only plagioclase peak in the rock at $3.20 \AA$ was lower than in the interface.

In the bottom part of Fig. 6d the XRD shows that the rock consisted of a high proportion of feldspar-plagioclases with a small amount of pyroxene. The few phyllosilicates seen may be chlorite. In the XRD of the interface $B$. stipata-rock (the upper part of the figure) some amounts of plagioclases can still be observed. In addition, there are four typical peaks for calcium oxalate, apart from a large amount of amorphous material. The XRD confirms that the band at $1400 \mathrm{~cm}^{-1}$ in the IR of the interface indicates the presence of carbonates because it has a peak at $3.02 \AA$.

Electron microscopy also provided useful information. Under the thallus of $X$. elegans allophanes and imogolite fibres were observed (Fig. 7). Whilst under the thallus of $B$. stipata many bacteria were found.

\section{Discussion}

Light microscopy is useful for observations of the distribution of hyphae below the thallus and within spaces be- 


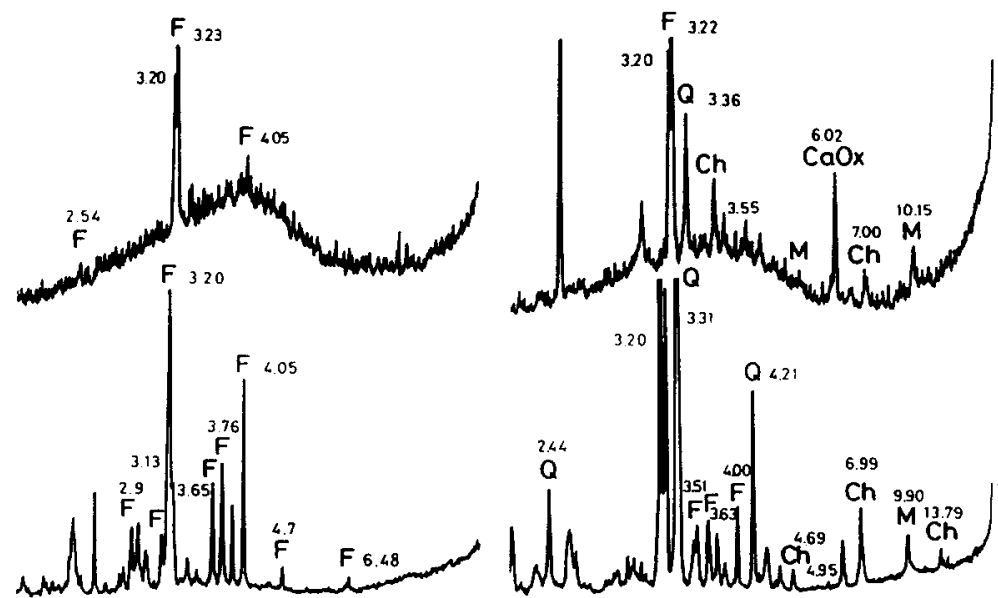

A
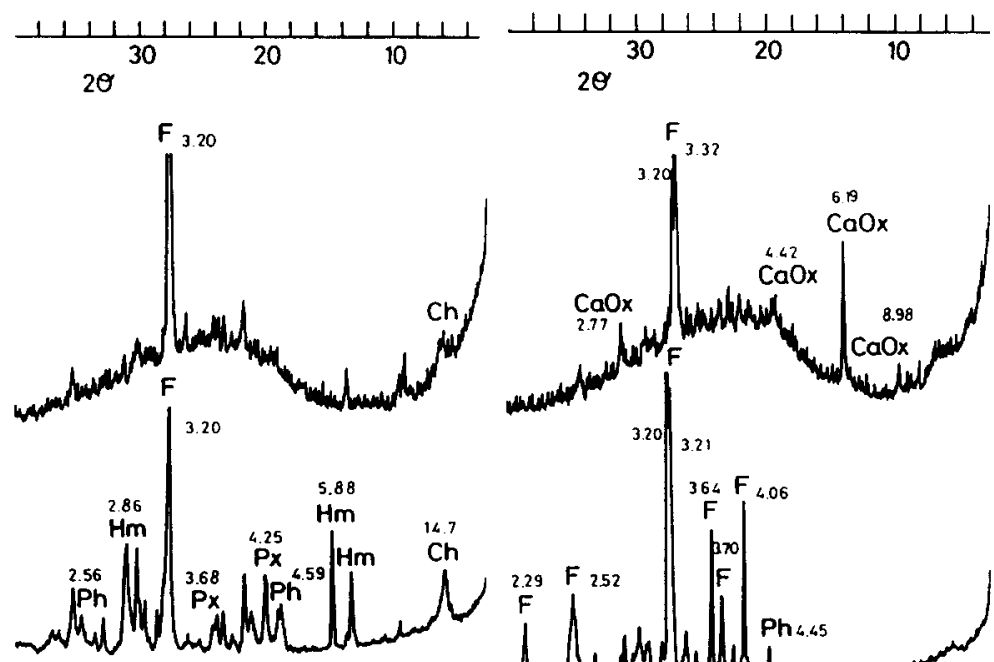

$3.20 \mathrm{~F}^{3.32}$

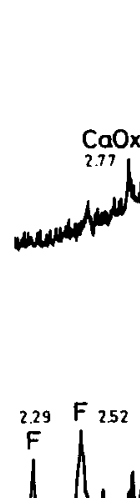

C

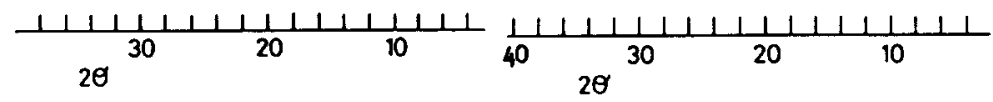

Fig. 6. X-ray diffraction diagrams (cobalt target) of rock (lower curve) and rock scraping between rock and lichen (upper curve). A Xanthoria elegans, B Lecidea lapicida, $C$ Rhizocarpon geographicum, and $D$ Bacidia stipata. $\mathrm{CaOX}$ Calcium oxalate, $\mathrm{Ch}$ Chlorite, $F$ Feldspar, $P h$ Phyllosilicate, $M$ Mica, $P x$ Pyroxene, $Q$ Quartz, $H m$ Hydromagnesite tween the mineral grains of the rock. Unfortunately this is difficult to illustrate with black and white photographs. The use of crossed nicols (polarized light) makes it easier to observe loose mineral particles both beneath and within the thallus.

This technique has been used by Walton (1985) in a study of crustose lichens from Antartica. In the present study, the use of crossed nicols showed the presence of minerals inside the thallus of $R$. geographicum, but not those inside the thallus of L. lapicida, although both are crustose lichens. Earlier observations by Ascaso (1985) have shown minerals in the thallus of $R$. geographicum on granite in the temperate region. At the moment, there is no theory to explain why some lichen species which are well attached to the rock substrate accumulate minerals inside the thallus, while others do not. The explanation may lie in the type of rock on which they are found. Light microscopy must be supplemented by other techniques to detect the presence of clay minerals. XRD corresponds with the observations made by means of IR. The importance of the groups formed of $\mathrm{Si}-\mathrm{O}, \mathrm{AlOH}$ and $\mathrm{Si}-\mathrm{O}-\mathrm{Al}$ bear out the observations of Wilson and Jones (1983) in the sense that the weathering of minerals by lichens may turn them into siliceous residues and that they may form poorly ordered products. The lower intensity of XRD response for interface material when compared with parent rock is to be expected. In the rock powder the minerals are better crystallized than in the interface mixture of minerals, and amorphous material. Only in $R$. geographicum a greater intensity was observed for the feldspars in the interface than in the rock. However, the pyroxenes, hydromagnesite and phyllosilicates found in the rock had disappeared completely, possibly providing the thallus with cations. As a result, they were not extracted so extensively from the feldspars. It may also be that the feldspar weathers less in this rock than in the other rocks that have been studied.

The lichens $X$. elegans and $L$. lapicida both grow on andesite. $X$. elegans has feldspars in its interface which have peaks of a lower intensity than those of the rock and a smaller number of reflections, apart from a important 


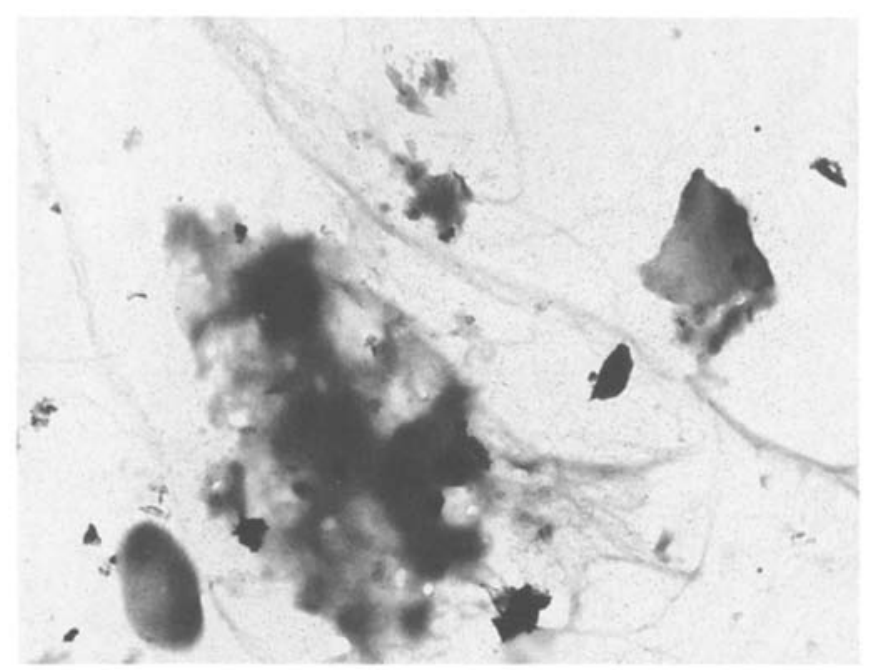

Fig. 7. Minerals at the interface between the thallus of $X$. elegans and the volcanic rock substrate

amount of gels. EM has shown imogolite, allophanes and amorphous material in the interface. The oxides $\mathrm{Al}$ and $\mathrm{Si}$ are the ones causing allophanes to form, while imogolites come into existence later, which may finally lead to halloysites.

The rock on which L. lapicida is found has quartz as well as the feldspars. The presence of phyllosilicates (as chlorite) in this lichen is also important. In addition to the lower peaks of the feldspars and the presence of amorphous materials already described for other species, there are quartz, chlorite and decayed micas of the illite type in the interface. It is difficult to be certain whether the micas of the illite type $(10.15 \AA)$ are only a product of decay or whether some of those clay minerals are newly formed in the lichen-rock contact area. Jones and Wilson (1986) also found that the evidence for clay mineral formation beneath the thallus was inconclusive. Below the thallus of $L$. lapicida calcium oxalate was also found, but this aspect will be discussed later since this compound is more abundant under the thallus of $B$. stipata.

B. stipata is the only endemic species studied. Both, light microscopy (Fig. 4a, b) and XRD show that this species had a strong weathering action. The presence of cryptoendolithic bacteria is typical of rocks in continental Antartica (Friedman 1982; Friedmann and Weed 1987). In the present study, the bacteria were found underneath and inside the lichen thallus in the weathered area of the rock. Here it is difficult to distinguish accurately between where the thallus really ends and the mineral substrate begins. Probably bacteria and thallus increasingly interact with each other and enhance weathering. This thallus is also found to include very significant amounts of calcium oxalate $\left(\mathrm{Ca} \mathrm{C}_{2} \mathrm{O}_{4} 2 \mathrm{H}_{2} \mathrm{O}\right)\left(\right.$ at $\left.2.5 \mathrm{H}_{2} \mathrm{O}\right)$ (weddellite) in the interface, as well as a small amount of calcite (the latter with a peak at $3.02 \AA$ ).

Jones et al. (1980) found calcium oxalate monohydrate $\left(\mathrm{CaC}_{2} \mathrm{O}_{4} \mathrm{H}_{2} \mathrm{O}\right)$ under the thallus of Pertusaria corallina growing on basalt. In a later study of lichens on calcareous rocks, Ascaso et al. (1982) found both forms of calcium oxalate monohydrate (whewellite) and dihydrate (weddellite), the latter in very small proportions. The dihydrate form is the one less frequently found in the lichen-rock interface, although Wadsten and Moberg (1985) found it on the surface of several lichen species by using SEM. Oxalate formation is due to the oxalic acid produced by the fungal hyphae but at the moment it is not clear why the dihydrate form is found. Calcium carbonate (calcite), found in this interface, may arise from thallus or atmospheric reactions. It may be the sedimentary nature of the rocks on which $B$. stipata grows which causes this type of weathering with the formation of oxalates and carbonates, which are not observed in the species studied. The amorphous materials were very abundant in this interface, but were also observed in the other three interfaces studied. They are a mixture of basically $\mathrm{Fe}, \mathrm{Al}$ and $\mathrm{Si}$ amorphous materials.

In this study a range of weathering activity was observed. B. stipata, the only endemic Antartic lichen, seems to develop the greatest substrate-weathering activity, whilst the cosmopolitan $R$. geographicum developed the lowest activity in Antartica.

Crystalline oxalate, imogolite, carbonates (calcite) allophanes and amorphous material are all apparently formed in the lichen-rock contact area. It is this type of weathering which predominates according to Wilson and Jones (1983)-in low temperature soils and which is characterized by the formation of non-crystalline or poorly organized materials and by organic-mineral complexes. Since all the species studied have shown weathering activity, the importance of this for pedogenesis in the terrestrial ecosystems of maritime Antarctica must be considerable.

Acknowledgements. We are pleased to acknowledge that this work was supported by a grant number PB87-0229 from the Comision Asesora de Ciencia y Tecnologia. We are grateful to Mr. F. Pinto and M. T. Carnota for technical assistance, and to Prof. Kappen and William Sanders for help with the English manuscript.

\section{References}

Ascaso C (1985) Structural aspects of lichens invading their substrata. In: Vicente C, Brown DH, Legaz E (eds) Surface physiology of lichens. Universidad Complutense, Madrid, pp 87-113

Ascaso C, Galvan J, Ortega C (1976) The pedogenic action of Parmelia conspersa, Rhizocarpon geographicum and Umbilicaria pustulata. Lichenologist 8:151-171

Ascaso C, Galvan J, Rodriguez Pascual C (1982) The weathering of calcareous rock by lichens. Pedobiologia 24:219-229

Duchafour P (1979) Alteration des roches cristallines en milieu superficiel. Sci Sol 2-3:87-89

Friedman EI (1982) Endolithic microorganisms in the Antarctic cold desert. Science 215:1045-1053

Friedmann EI, Weed R (1987) Microbial trace-fossil formation, biogenous, and abiotic weathering in the Antarctic cold desert. Science 236:703-705

Galvan J, Rodriguez C, Ascaso C (1981) The pedogenic action of lichens in metamorphic rocks. Pedobiologia 21:60-73

Jones D, Wilson MJ (1985) Chemical activity of lichens on mineral surfaces-A review. Int Biodeterior Bull 21:99-104

Jones D, Wilson MJ (1986) Biomineralization in crustose lichens. In: Leadbeater BSC, Riding $\mathbf{R}$ (eds) Biomineralization in lower plants and animals. Clarenton Press, Oxford pp $91-101$ 
Jones D, Wilson MJ, Tait JM (1980) Weathering of a basalt by Pertusaria corallina. Lichenologist 12:277-289

Jones D, Wilson MJ, Mc Hardy WJ (1981) Lichen weathering of rock-forming minerals: application of scanning electron microscopy and microprobe analysis. J Microsc 124:95-104

Kappen L, Friedmann El (1983) Ecophysiology of lichens in the Dry Valleys of southern Victoria Land, Antarctic. II. $\mathrm{CO}_{2}$ gas exchange in cryptoendilithic lichens. Polar Biol 1:227-232

Kappen L, Bölter M, Kühn A (1986) Field measurements of net photosynthesis of lichens in the Antarctic. Polar Biol 5:255-258

Lindsay DC (1978) The role of lichens in Antarctic ecosystems. Bryologist 81:268-276

Syers JK, Iskandar IK (1973) Pedogenic significance of lichens. In: Ahmadjian V, Hale ME (eds) The lichens. Academic Press. New York, pp $225-248$

Wadsten T, Moberg R (1985) Calcium oxalate hydrates on the surface of lichens. Lichenologist 17:239-245
Walton DWH (1985) A preliminary study of the action of crustose lichens on rock surfaces in Antarctica. In: Siegfried WR, Condy PR, Laws RM (eds) Antarctic mutrient cycles and food webs. Springer, Berlin, pp 180-185

Wilson MJ, Jones D (1983) Lichen weathering of minerals: implications for pedogenesis. In: Wilson RCL (ed) Residual deposits: surface-related weathering processes and materials. Special publication of the Geological Society, Blackwell, London, pp 5-12

Wilson MJ, Jones D (1984) The occurrence and significance of manganese oxalate in Pertusaria corallina (Lichenes). Pedobiologia $26: 373-379$

Wilson MJ, Jones D, Russell JD (1980) Glushinskite, a naturally occurring magnesium oxalate. Min Mag 43:837-840

Wilson MJ, Jones D, McHardy WJ (1981) The weathering of serpentinite by Lecanora atra. Lichenologist 13:167-176 